New Zealand Journal of Industrial Relations, 19(2): 161-174

\title{
COMMENTARY
}

\section{Industrial Relations Research in New Zealand: the State of a Discipline}

\author{
Pat Walsh*
}

Industrial relations in New Zealand is a vital and active discipline. It compares more than favourably with similar disciplines in research output - indeed I would suggest it out performs most comparable disciplines - and the last decade or so has been an exciting time to be researching industrial relations.

I think a logical place to start in assessing research in any discipline in a particular country is in the national journal of that discipline. In New Zealand industrial relations, the hard work put in by John Deeks and Margaret Wilson in establishing the New Zealand Journal of Industrial Relations back in the mid-1970s has been amply rewarded. It is now in its 18 th year as a refereed journal. In that time it has had three issues each year and has seen the publication of more than 300 articles, numerous book reviews and of course in each issue the indispensable industrial relations chronicle by Bert Roth. Measured simply in terms of output, the NZJIR offers evidence to support the claim of a vital and active academic community.

The success of the NZJIR stands in contrast to the record in other comparable academic disciplines. Anthropology, a discipline of similar size has no refereed journal; sociology, a much larger discipline, only recently established its own local refereed journal; management publishes only one issue per year of the New Zealand Journal of Business (although I understand this is about to increase); marketing has no refereed journal; history, political science, education and economics, all much larger disciplines, match industrial relations in having a regular refereed journal, although not all manage three issues each year.

In addition to the NZJIR, industrial relations researchers in New Zealand make use of many other publication outlets. They publish in related discipline journals and they contribute books and chapters in books to the growing academic book publishing market in New Zealand. The biannual Labour and Employment Workshop, notwithstanding its wider labour market focus, has been a major stimulus and forum for industrial relations research as well. In recent years, the Australian connection has been an important source of research

Victoria University of Wellington. The author wishes to thank Rose Ryan and Peter Brosnan for comments on an earlier draft. 
and publication. The now annual conference of the Association of Industrial Relations Academics of Australia and New Zealand (AIRAANZ) has grown from a small affair of friends and enemies to a large gathering. In 1989, 60 attended the Wollongong conference; almost three times that many were in evidence in Sydney in February this year. The conference has been a major source of cross-fertilisation for single country research while, as Nigel Haworth observed in his presidential address this year, it has also played its role in stimulating a growing recognition of the opportunities and-need for comparative transTasman research (Haworth, 1994). The Australian connection surfaces through the publication of New Zealand research in Australian industrial relations journals, which have grown in number to five in recent years. New Zealand scholars also publish in international industrial relations journals, although with some difficulty and not perhaps in the numbers warranted by the degree of research activity within the discipline. I shall return to this point later.

\section{The focus on policy and practice}

So, there is much evidence of activity. But, it may fairly be asked, what kind of activity? A qualitative assessment is more important than a simple count of articles. A helpful source is the recently published annotated index to the NZJIR for the period 1976-1992 (FIRRE, 1993). The picture that emerges is decidedly one of a discipline focused heavily on analysis of and comment upon current industrial relations policy and practice. Theory and self-conscious efforts to develop theoretical frameworks are notable by their absence. The NZJIR index is divided into eight major categories - theory is not one of them. The major categories are further subdivided into 28 categories, only one of which refers to theory - trade union theory, a sub-category with just two entries, one of them by an Australian.

There has not been one article in the 18 years of the NZJIR which attempts explicitly to build a general New Zealand theory of industrial relations. Few articles have set themselves the task of building middle range theories around topics such as bargaining structure and development, union structure and activities or the role of the state. This is not to say of course that industrial relations academics in New Zealand have been entirely atheoretical, but for self conscious theorising we have to turn away from the national journal to other publication avenues. Even then, conscious theorising is not common.

Why should this be the case? It is often suggested that the avoidance of theory is a distinctive New Zealand characteristic. If this is true then it would seem that the answer is cultural rather than disciplinary. As early as the second issue of the NZJIR, John Deeks observed that "it is a truism that there is in New Zealand culture a widespread if inarticulate suspicion of ideas, of theory, of ideology and a general preference for the practically useful, for the matter of fact treatment of things, for the pragmatic" (Deeks, 1976: 26). He went on to comment, somewhat presciently in view of the record of the next 17 years, that in industrial relations discussion of theoretical issues is downplayed in favour of historical and descriptive studies. (I am sure some historians would bridle at the implication that their discipline is atheoretical, but an assessment of two disciplines is altogether more than I can handle right now. In fact I suspect that the theoretical status of labour history is rather 
more firmly established than that of industrial relations but this may have more to do with the peculiarities of the current crop of labour historians in New Zealand.)

This assessment of the neglect of theory in NZ is not confined to industrial relations. Wystan Curnow observes in Essays on New Zealand Literature that "The New Zealand mind has an unhealthy distaste for theory" (1973: 155). And in political science, Kenneth Janda (1980) in Political Parties: a Cross-National Survey comments in his evaluation of New Zealand studies of political parties on the disappointing lack of imaginative theoretical studies.

The determination of industrial relations academics in New Zealand to analyse and comment upon current industrial relations policy and practice may be an important factor in the apparent lack of theoretical work in the discipline. This practical orientation has of course been a continuing feature of the discipline of industrial relations in most countries. In this regard, industrial relations stands in contrast with economics, one of its closest disciplinary partners. As John Niland once observed, many industrial relations scholars are "refugees from the intellectually beautiful but often impractical world of deductive neoclassical economics" (quoted, in Adams, 1988: 5).

In New Zealand, there has been a very high expectation that industrial relations academics will play this analytical role. It is an expectation fed by the media which constantly press for brief comment and lengthier analysis from academics on new government policies or legislation, on major Court decisions or major disputes, on policy debates between or within the parties and on major new developments in industrial relations practice. This current policy role is also shaped by the unusual degree of scrutiny which industrial relations practitioners in New Zealand give to industrial relations research and to policy comment by academics. It is not an infrequent experience for industrial relations academics to find their work the subject of either favourable or (more often) unfavourable comment by an industrial relations practitioner or by politicians.

I think that by and large this is a good thing. There is no reason, at least not one that I am aware of, why non-academics should not criticise academic research. Even the most liberal definition of academic freedom does not extend to freedom from community criticism. Provided criticism is backed up in the usual way by alternative theory, data or interpretation, one cannot quibble. The notion of academic accountability to the community is not always an easy one to disentangle from academic accountability to their peers, but there can be no gainsaying the community's right to comment on the research it funds. Moreover, it seems to me that industrial relations academics have a responsibility to use whatever means possible to communicate the results of their research to industrial relations practitioners and policy-makers.

Academics come under pressure to contribute to public and policy debate about any number of industrial relations issues. Pressure comes from the community and from academics themselves. Most academics enter industrial relations because they care about the issues, the people involved and the outcomes and want to see the issues debated rationally and with some relationship to reality. Mix in the fact that it is a policy area which attracts more than its fair share of rhetoric and distortion and there is a very high likelihood of academics entering the debate voluntarily so as to "put things right". This generates considerable 


\section{Pat Walsh}

pressure for applied research. Academic awareness that any comment they make has a high chance of attracting further comment by the parties fuels a desire on their part to get it right by undertaking research on the major issues of current debate. Accordingly, conscious theoretical work tends to be put to one side as a luxury which few can afford. It indicates the degree to which industrial relations research is driven by a perceived need to respond to events in the world outside. I do not disapprove of this orientation. It has played an important role in my own approach to the discipline over the last decade. But current policy and practice needs to be placed in a wider historical, comparative and theoretical context if academic research is to make a distinctive contribution. Without this, there is the danger of researchers falling into the trap of being good journalists, and I say this without meaning any criticism of journalism. But academics are not, or should not, be journalists,

Another factor in the relative neglect of theory may be New Zealand's relative insignificance on the world academic stage which can make it difficult to publish in international journals. A colleague of mine has carefully preserved a rejection letter from a major international journal explaining that the journal simply was not interested in publishing anything about New Zealand. Others can relate similar experiences. One way to publish in international industrial relations journals is to have a gripping story to tell which any editor will snap up greedily regardless of theoretical content. Because stories about New Zealand are by definition not gripping to editors of international journals, the incentives are simply not to bother submitting it to international journals but to submit to Australasian publication outlets, where the academic tradition is practical rather than theoretical, and, as importantly, where the peer group is as much the practitioner world as it is other academics. All this reinforces the incentives to do applied research.

The second way in which this view of New Zealand as unimportant operates is a disregard for the significance of events in New Zealand as offering the basis for original theoretical development. This lack of international regard for the New Zealand experience of industrial relations influences our own choice of theoretical frameworks. We too easily accept theories developed elsewhere even though the context in which they were developed may have been very different. Very few industrial relations academics in New Zealand have begun to grapple with the theoretical implications of managing the employment relationship in a bicultural society. A notable exception is Rose Ryan's recent study of Nissan (Ryan, 1993).

\section{International perspective on industrial relations theory}

So, is one possible explanation that the neglect of theory is a distinctive New Zealand characteristic which is to be found in industrial relations as much as in other disciplines? An alternative explanation is to find the reason for the lack of theory in the discipline of industrial relations internationally rather than in anything specific to New Zealand. Industrial relations scholars have worried throughout the life of the discipline about its lack of theoretical work. This is summed up in Richard Hyman's remark that "it is a commonplace that the study of industrial relations is typically descriptive and pragmatic, the analysis unsupported by an explicit theoretical framework" (quoted in Plowman, 1989: 6). In his presidential address to the 1989 AIRRANZ conference, David Plowman observed 
that the struggle by industrial relations for academic respectability had been long and difficult. He argued that a major reason for that was the discipline's theoretical weakness. Plowman could not refrain from acidly noting that "elegant and irrelevant theories and models may command more attention and credence" but he conceded the main point industrial relations's neglect of theory.

This view is still held by some in Australasian industrial relations. Braham Dabschek (1994) claims that industrial relations lacks distinctive theoretical frameworks and continues to import them from other social science disciplines. Dabschek argued that this makes industrial relations vulnerable to takeover from rival disciplines. For him, it is imperative that industrial relations scholars set themselves the task of developing a theoretical framework unique to industrial relations which embraces the distinctive subject matter of the discipline and which offers protection against imperialist disciplines. Plowman argues that this vulnerability is compounded by the declining significance of the traditional concerns of industrial relations research. This means that industrial relations as an academic discipline can no longer overcome its lack of theoretical respectability by pointing to its continuing relevance to current industrial relations policy and practice.

So perhaps rather than being distinctively New Zealand in its orientation, the industrial relations discipline in New Zealand is typical of the wider international industrial relations community - atheoretical, oriented to current policy and practice but of decreasing utility in that regard. A depressing picture; if it is valid, the future for industrial relations looks bleak. I disagree with this analysis. I believe it stems from two misunderstandings - one of the role of theory in social science, and the second of the essential subject matter of the discipline of industrial relations.

The standard applied by Dabschek and Plowman is harsh and is not one that other social sciences, with the possible exception of neo-classical economics, could match. They also lack theoretical frameworks unique to them. The social sciences, theoretically and methodologically, are interdisciplinary and the boundaries between them muddled. My experience of graduate work in a major United States political science department made it clear that other disciplines have exactly these debates. Political science's remarkable inferiority complex with regard to economics as the scientific discipline par excellence and the continuing deference to theoretical constructs and models drawn from economics was for me as a graduate student a continuing source of frustration. Theoretical purity or uniqueness is unattainable in the social sciences. Theoretical development is a continual process of importing, transferring and modifying insights from other disciplines. Industrial relations can be no exception. As Roy Adams observes "If one classifies as industrial relations theory only those theoretical constructs unclaimed by other fields then it is probably true that the set is sparsely populated. But such a criterion is much more strict than that applied to other fields" (1988: 6). Instead, Adams argues for a wider understanding of industrial relations theory as the body of theory guiding research into the employment relationship regardless of whether or not it is also claimed by another field.

If this approach is taken, the theoretical status of industrial relations looks somewhat healthier. Adams cites the setting up during the 1980 s of the industrial relations Theory Study Group within the International Industrial Relations Association and the degree of interest in that as illustrative of the level of theoretical concern in the discipline. Using his 
definition of industrial relations theory, Adams found a much greater degree of theoretical work in the literature. Similarly, a different reading of industrial relations research in New Zealand produces a more positive account of its theoretical status. I went through the 1993 index to the NZJIR a second time and, hazardously relying on my own memory, reclassified the articles in terms of whether they contained, in Adams' terms, theoretical work. In this somewhat rough and ready reclassification, about 25 of the 267 articles published in the NZJIR between 1976 and 1992 were categorised as theoretical. With the deduction of articles by practitioners and policy-makers, this means that over 10 percent of the articles by industrial relations scholars contained a conscious attempt to theorise their subject matter.

Adams' approach is also helpful in clarifying the misunderstanding of the core subject matter of the discipline of industrial relations. Pessimism about the relevance of industrial relations stems from a narrow, view of its subject matter. In this narrow view, industrial relations is defined as the study of unions, employer associations, collective bargaining, arbitration and so forth. But an alternative view, such as that of Adams, is that industrial relations is the study of the employment relationship, and in particular how that relationship is governed or regulated. The employment relationship is historically contingent. It unfolds over time and acquires different institutional expressions or forms in different periods. For a very long period in New Zealand, the government or regulation of the employment relationship involved a key role for unions, employer associations, arbitral tribunals, collective bargaining and even state intervention. It was appropriate then for anyone interested in the employment relationship to study these institutions. If they decline in importance, if other institutional expressions acquire a more significant role, then the focus of research should change. It is a mistake to be more attached to studying the institutional form of the employment relationship than to the employment relationship itself.

It is I think fair to say that the research focus in New Zealand industrial relations has been institutional, and, equally, that this has been appropriate given the manner in which the employment relationship has been regulated historically. The key issue is whether the industrial relations research agenda is now adjusting to what John Purcell (1994) has recently called the end of institutional industrial relations. I shall return to this issue later, but first I want to offer some assessment of the last two decades of industrial relations research in this country.

\section{Revising the institutional focus}

John Dunlop (1958), in his still indispensable study, observed that industrial relations was a crossroads at which a number of disciplines met. In New Zealand industrial relations, the disciplines which have most strongly asserted their right of way at the crossroads have been law and economics. History, political science and sociology have made their presence felt while generally being content to let the big two pass unimpeded. But at the same time, it is possible to talk of a distinctively industrial relations focus from scholars who, whatever their disciplinary background, by their choice of subject matter - institutional industrial relations - and their approach to it - practical and policy oriented - have divorced themselves from their discipline of origin. Ironically, it is perhaps the insistently 
theoretical nature of much industrial relations research that allows us to speak of an ndustrial relations discipline in New Zealand. Had researchers remained wedded to the heoretical and methodological tools of their parent disciplines, notwithstanding crossdisciplinary similarities, industrial relations research in New Zealand might not have achieved the limited degree of unity that it has.

Not unexpectedly, the institutions of industrial relations have comprised the largest research area. This reflects the crucial role played by those institutions in regulating the employment relationship. However, current research suggests, as Purcell has stated for the British context, that "we are seeing the progressive collapse of the system of industrial relations, marked especially by the end of institutional mechanisms created over the last 100 years to bring order and stability to industrial relations" (1994: 5-6). This poses researchers with a difficulty. The historical significance of these institutions and their continuing, albeit diminished contemporary role makes it important to chart the changes taking place. Moreover, their contemporary decline may not necessarily be permanent. It is foolish to read fundamental historical change off today's headlines.

But it is undeniable that most of the traditional institutions of industrial relations in New Zealand are currently in decline. Increasingly, the employment relationship is governed in different ways. More workplaces are non-unionised, more employment contracts are individual rather than collective, fewer employment contracts - whether individual or collective - are negotiated in any meaningful sense of the term, industrial conflict is on the wane, arbitration is an historical memory and conditions of employment, in particular payment systems, are in many cases substantially altered. My earlier comments about the danger of being too attached to the institutional expression of the employment relationship are apposite in this context. It is vital that these institutions continue to be the subject of research and there is substantial and creative research on-going in those areas, most obviously in the analyses by Raymond Harbridge and Kevin Hince of their collective bargaining and union membership data-bases (for examples, see Harbridge, 1993 and Harbridge and Hince, 1994). But it is equally vital that researchers do not lose sight of the importance of researching the newly emerging patterns in the regulation of the employment relationship.

The one exception to this picture of institutional decline is in the area of legal institutions. The second largest area of research in New Zealand industrial relations has been the legal environment. This includes analysis of governments themselves, the content of legislation and its application and interpretation. This reflects, on the one hand the historically dominant role of the state in industrial relations, and on the other the number of extremely able legal academics interested in labour law. The Employment Contracts Act gave a fillip to both practising and academic lawyers - indeed at the time of its passage, one of their number, so struck were he and his colleagues by the glittering opportunities opened up to them by the Act, confessed that they were in what could only be described as a feeding frenzy.

It is clear that the law will continue to be a major area of research. Its role in regulating the employment relationship is becoming more rather than less important. The wheel has turned full circle in this regard. The state has disengaged from its traditionally crucial role in the determination of employment conditions but has come to play a progressively larger 
role in regulating the conduct of the employment relationship once it is formed.

This means that knowledge of the legal environment is increasingly important for human resource and industrial relations professionals and academics alike. There is an awareness of the complexity of these issues. I have noted in a field study I am currently undertaking of decentralisation of human resource management in the public sector, that even in highly decentralised environments, chief executives typically retain authority over disciplinary decisions. For academics, it is vital that labour law be an established component of teaching programmes, particularly those aimed at practitioners. I think there is little danger of it falling off the active research agenda. It is an area that nicely illustrates the vital connection between research and teaching that is common to all areas of industrial relations. The next three largest bodies of industrial relations research, all of comparable size, have been gender and minority groups, employment and unemployment and occupational health and safety. All three reflect the policy importance attached to them over the last decade or more and will continue to be important to the industrial relations research agenda in New Zealand.

\section{Neglect of management in industrial relations research}

But now, I want to shift my focus away from what has been done to what has been left undone. It is a common criticism of industrial relations research that it ignores management. Plowman in the AIRAANZ presidential address I referred to earlier, suggested that industrial relations has left itself open to criticism by its inadequate study of management. He argues that the common perception of industrial relations is as a discipline focused on unions and collective bargaining "almost to the point of adulation" (1989: 9).

The index to the NZJIR does not include a category for management and there have not been many articles published on management strategy in the Journal - Cammock's (1987) study of Motonui, Ammon's (1989) study of Electricorp, Brosnan (1990) on the retail industry and Hince (1986) on general industrial relations management are among the few. Management strategy in industrial relations is an area where more research has been published outside the NZJIR than in it, and possibly more by researchers not in the industrial relations mainstream. The NZJIR has never published an article assessing either empirically or theoretically the development and status of HRM in New Zealand. Peter Boxall has focused on these issues with a series of articles, all published outside the NZJIR (Boxall and Dowling, 1990, Boxall, 1990).

I believe this neglect of management and its industrial relations or human resource strategy is the major deficiency in industrial relations research in New Zealand and the area which demands the biggest effort in the near future. The crucial issue, as Keith Sisson (1993) has put it, is whether there has been a paradigm shift in the regulation of the employment relationship. Has the disintegration of institutional industrial relations been accompanied or even to some degree caused by the rise to predominance of HRM? Purcell observes that it is widely argued that an alternative system of regulating the employment relationship has emerged, which ensures the fair representation of all interests in the workplace. 
Sophisticated human resource management is claimed to have replaced institutional industrial relations. The picture that has developed since the $1980 \mathrm{~s}$, says Purcell, is one of "enterprises, freed from the rigidities of collective bargaining, developing labour practices based on investment and added value which empowered employees through teamwork and partnership to work with management for the benefit of the firm .... The essence of the argument is that competitive pressures are forcing companies to develop 'organisational specific labour policies' (Dore, 1989) based on the internal labour market in order to develop firm-specific, more highly skilled labour practices" (1994: 19). A more sceptical view is that institutional industrial relations has begun to collapse but without any replacements having emerged to regulate the employment relationship other than a reliance on managerial prerogative.

So a key issue is what is management doing and why are they doing it? I would like to refer briefly to two competing, and I suspect ultimately irreconcilable answers to this question. In an important 1993 article, Harry Katz sets himself the task of explaining a major aspect of the decline in institutional industrial relations - the breakdown of traditionally centralised collective bargaining in a range of countries and its replacement by much more decentralised bargaining patterns. He assesses three explanations of the emergence of decentralised bargaining.

The first is shifts in bargaining power: "As employers acquired more bargaining leverage, a change caused by intensified international competition and declines in union membership and political strength, they pushed to decentralise the structure of bargaining with the expectation that this change would produce bargaining outcomes more favourable to management." (1993: 13). The second hypothesis is grounded in workplace reform - the emergence of what Katz, following Streeck's (1987) pioneering study of the "uncertainties of management and the management of uncertainty", calls union/management productivity coalitions focused around changes in work organisation: ". . . the identification of innovations and the implementation of new forms of work organization require direct participation by workers and local union officials ... A related claim is that the new work organization involves changes in a variety of employment practices, including team work, performance-based pay methods, participatory programmes, extensive training, and in some cases, employment security" (1993: 14). The third hypothesis looks at the diversification of corporate structures and worker interests. Corporate decentralisation increases the independence of business units and passes responsibility for industrial relations to lower level managers. The other side of this is "a widening diversity in worker interests (or erosion of worker solidarity) [which] can explain bargaining decentralisation in a manner that parallels the corporate diversification argument" (1993: 16).

Katz opts for workplace reform as the driving force for bargaining decentralisation. $\mathrm{He}$ finds little evidence to support the corporate and worker diversification hypothesis. $\mathrm{He}$ concedes some support for the bargaining power thesis. Management has strongly pushed for decentralisation and central unions have (with the exception of Australia) opposed it. But it is not clear that management was greatly disadvantaged by centralised bargaining and local unions have often supported decentralisation. Local union leaders and workers enjoy their participation in shop floor and strategic decisions and benefit from more flexible work schedules. This leads Katz into his conclusion that the key factor is workplace reform. He argues that "both labor and management gain clear advantages from the work restructuring 
that is under way in many workplaces .... It also appears that local bargaining is essential for the identification and implementation of new more flexible forms of work organisation. Thus, I am led to the view that work reorganisation has played a significant role as a cause of bargaining structure decentralisation" (1993: 17).

Thus, Katz opts for the sophisticated human resource management side of the ledger. Product market shifts, technological change, new managerial, worker and even local union attitudes generate pressure for new forms of work organisation whose operation is incompatible with the traditional ways of institutional industrial relations. For Katz this is a conscious management strategy, and one in many cases supported by workers and local unions. Moreover its key components, as identified by Katz, fit the sophisticated human resource management model - innovative workplace arrangements, direct participation by workers and local union officials, team work, performance-based pay methods, participatory programmes, extensive training, and employment security. Many other studies of course would add non-unionisation to this list of features. Katz did not address this because he was looking at collective bargaining, albeit decentralised, which almost by definition, at least outside New Zealand, involves unions. But many other studies would stress the importance of non-unionisation to the sophisticated human resource management model.

However, the sceptics have not gone to ground. The virtues of the heavily empirical, practice and policy oriented tradition of industrial relations research have rarely been more in evidence than in offering an alternative answer to the question of what management is doing and why it is doing it. This is particularly so in the United Kingdom where three Workplace Industrial Relations Surveys (WIRS) over the last decade give a comprehensive data base upon which to base an assessment. Purcell comments that WIRS3, the same survey which is relied upon to document the collapse of institutional industrial relations in the United Kingdom "finds virtually no evidence across the country for [the sophisticated human resource management] type of employment pattern and less than one percent of managers responsible for personnel used the title of human resource manager. Instead they paint a compelling and depressing picture of the emergence of the non-union sector based firmly around the principle of cost minimization" (1994: 21). The non-union sector in the United Kingdom reported better employee relations and almost no strikes, but it experienced higher turnover and injuries; it used performance related pay more but did not use job evaluation as a means to establish fair internal differentials; perhaps as a result, it had higher pay differentials between top and bottom earners and a higher proportion of low earners; the non-union sector is more likely to use casualised labour and to rely on compulsory redundancy; its dismissal rate is twice that of unionised firms and it is much less likely to have grievance procedures, consultative committees or to give any information to employees. Sissons agrees, arguing that there is evidence only of what he calls "fragments" of human resource management in the United Kingdom, and paradoxically, that these fragments are more visible in union than non-union firms.

The disturbing conclusion from the sceptics is that nothing has emerged to replace institutional industrial relations; sophisticated human resource management remains the preserve of a few firms. This means that, as unionisation continues to fall, increasingly, the employment relationship is once again governed by managerial prerogative. Sophisticated human resource management models, say the sceptics, are found more in texts than in reality, more in management departments than in workplaces. 


\section{Research agenda for the future}

Is this the case in New Zealand? We don't know but we should try very hard to find out. I think that this must be the major research agenda in New Zealand industrial relations over the next decade. It will require work in some of the less well developed areas of the discipline. I have commented earlier on the lack of research on management strategy itself. A key issue identified more than a decade ago by Purcell and Sisson (1983) - the impact of corporate decision-making on the conduct of industrial relations/human resources and the degree of autonomy permitted by the corporate division - remains of vital importance. I am finding it fascinating in my current project on the decentralisation of human resource, that different public sector agencies, operating in broadly similar environments, are making quite different choices on these issues. I will mention just four of the many issues relevant to management strategy which I think need to be the subject of major research programmes - workplace reform, employee involvement, payment systems and numerical flexibility.

Understandably, given its relatively recent emergence, workplace reform, and the range of issues subsumed under that category, such as production systems, work organisation itself, teamwork, training and so forth, have not been well researched so far in New Zealand. But there are signs that this is changing exemplified by the case study programme by the Institute for Social Research and Development in Christchurch, and, as recent issues of the Labour Research Bulletin show, other case studies are under way also. These studies must be informed by a critical approach - there is an active debate on the value and significance of workplace reform. The recent lecture tour by Jane Slaughter brought this debate to the fore.

Industrial democracy or employee involvement is another key area for the future. Allan Flanders' work was premised on the argument that the virtue of, and justification for, collective bargaining was that it made workers industrial citizens - it gave them representation in the workplace. It was a simple and powerful argument about the dignity of labour. If collective bargaining is gradually disappearing, then what is replacing it as a source of worker representation in the workplace? Much is made of the new participatory workplace, where workers are given opportunities for input into the range of issues that affect them. But to what extent are these in place and how genuine are the participatory opportunities?

In a research agenda of this nature, payment systems and performance appraisal will be carefully scrutinised. Kohn's recent (1993) rubbishing of the very notion of performancebased pay systems in the hallowed pages of the Harvard Business Review has elicited the expected outraged response from the performance pay industry. But Kohn, although not an industrial relations academic, relied upon the empiricist industrial relations tradition and conducted an exhaustive examination of the empirical literature before making his argument that there is no evidence that performance-based pay systems improve individual or organisational performance. The effectiveness of these systems has been a matter of continuing debate for many years and Kohn's dramatic restatement of the argument in the face of the widespread desire of human resource professionals to adopt performance-based pay systems and their much lower enthusiasm for skill-based systems makes this issue 


\section{Pat Walsh}

central to future research on the employment relationship. This raises a crucial issue. There is a performance pay industry of consultants with much vested in the assumption that performance pay works. If it doesn't, if it is, as Kohn concludes, all a charade "full of sound and fury signifying nothing", where will academics be found in this debate? Will they be in the pages of academic journals critically assessing the value of performance pay or in the seminar room preaching the latest fad and pocketing the consulting fee?

Numerical flexibility is an area that has received a considerable degree of research attention in recent years. But there are still important questions to be answered. At one level these are questions about the nature and extent of numerical flexibility in New Zealand. But this gives rise in turn to more fundamental questions about the nature of the employment relationship that is developing in the context of numerical flexibility strategies. Do employers accept a clear division between core and periphery, consigning the latter to a nether world of insecurity and exploitation? Or do the obligations of the sophisticated human resource management model run to requiring management to accept responsibility for all of the workforce, not just the favoured core? There are very important normative questions of equity and justice that come into play here and that are bound up with issues of gender, ethnic relations and disability.

It would be possible to continue at some length listing the components of a research agenda that addresses management strategy. I shall desist but will make one more general comment. The notion of management's industrial relations/human resource strategy connects back to the traditional concerns of institutional industrial relations at the same time as it links forward to wider issues of corporate strategy and structure and organisational culture which previously were thought of as outside the concern of those researching the employment relationship. It will be clear from this discussion that I am impatient with those who would maintain unnecessary and artificial disciplinary distinctions between industrial relations and human resources, between both of them and strategic management or both of them and organisational behaviour. The study of the employment relationship draws its resources from where it can and capitalises on the different analytical traditions embodied in different disciplines. The quality of future research on employment relations in New Zealand will depend to a significant degree on the ability of researchers to draw upon the theoretical and methodological insights of the different traditions that bear upon it.

\section{References}

Adams, R.J. (1988), Desperately Seeking Industrial Relations Theory, International Journal of Comparative Labor Law and Industrial Relations, 4(1): 1-10.

Ammon, C. (1989), Restructuring Electricorp: the Labour Process, Profit, Technology and Work Organisation, New Zealand Journal of Industrial Relations, 14(2): 109-118.

Boxall, P. and Dowling P. (1990), Human Resource Management and the Industrial Relations Tradition, Labour and Industry, 3: 195-214. 
Boxall, P. (Ed) (1990), Function in Search of a Future: Perspectives on Contemporary Human Resource Management in New Zealand, Auckland, Longman Paul.

Brosnan, P. (1990), Labour Market Flexibility and the Quality of Work: a Case Study of the Retail Industry, New Zealand Journal of Industrial Relations, 16(1): 13-36.

Cammock, P. (1987), Industrial Relations at Motonui - An Examination of a Successful Industrial Relations Strategy on a Large Construction Project, New Zealand Journal of Industrial Relations, 12(2): 71-80.

Curnow, W. (1973), Essays on New Zealand Literature, Auckland, Heinemann Educational Books

Dabschek, B. (1994), A General Theory of (Australian) Industrial Relations, Journal of Industrial Relations, 36(1): 3-17.

Deeks, J. (1976), Ideology and Industrial Relations in New Zealand, New Zealand Journal of Industrial Relations, 1(2): 26-31.

Dore, R. (1989), Where Are We Now: Musings of an Evolutionist, Work, Employment and Society, 3(3): 425-446.

Dunlop, J. (1958), Industrial Relations Systems, Carbondale, Southern Illinois University Press.

FIRRE (1993), New Zealand Journal of Industrial Relations: An Annotated Index of Volumes 1-17, 1976-1992, Dunedin, Foundation for Industrial Relations Research and Education.

Katz, H. (1993), The Decentralization of Collective Bargaining: A Literature Review and Comparative Analysis, Industrial and Labor Relations Review, 47(1): 3-22.

Harbridge, R. (Ed) (1993), Employment Contracts: New Zealand Experiences, Wellington, Victoria University of Wellington Press.

Harbridge, R. and Hince, K. (1994), Bargaining and Worker Representation under New Zealand's Employment Contracts Legislation, Relations Industrielles, 49(3): 561-581.

Haworth, N. (1994), Developing the Trans-Tasman Link: AIRAANZ and Comparative Analysis of Australian and New Zealand Industrial Relations, Presidential Address to the 8th AIRAANZ Conference, University of Sydney, February 10-12 1994.

Hince, K. (1986), The Management of Industrial Relations, New Zealand Journal of Industrial Relations, 11(1): 11-20.

Janda, K. (1980), Political Parties: a Cross-National Survey, New York, The Free Press. 


\section{Pat Walsh}

Kohn, A. (1993), Why Incentive Plans Cannot Work, Harvard Business Review, September-0ctober 1993: 54-63.

Plowman, D. (1989), Industrial Relations Teaching and Research: Trends, Pressures, Strategies, In M. Bray and D. Kelly (eds), Issues and Trends in Australasian Industrial Relations: Proceedings of the 4th Biennial AIRAANZ Conference, University of Sydney, AIRAANZ.

Purcell, J. (1994), The End of Institutional Industrial Relations, Paper presented at the 8th AIRAANZ Conference, University of Sydney, February 10-12 1994.

Purcell, J. and Sisson, K. (1983), Strategies and Practice in the Management of Industrial Relations, In G.S. Bain (ed) Industrial Relations in Britain Oxford, Basil Blackwell.

Ryan, R. (1993), "Japanisation" or a "New Zealand Way"? Five Years on at Nissan New Zealand, Working Paper 5/93, Industrial Relations Centre, Victoria University of Wellington.

Sisson, K. (1993), In search of HRM, British Journal of Industrial Relations, 31(2): 201210.

Streeck, W. (1987), The Uncertainties of Management and the Management of Uncertainty: Employers, Labour Relations and Industrial Adjustment in the 1980s, Work, Employment and Society, 1(3): 281-308 